\title{
Impending Danger: The Meaning of Danger as a Legal Requirement for Involuntary Psychiatric Treatment in the Norwegian Criminal Justice System
}

\author{
MARTIN MINDESTRØMMEN*
}

\section{Introduction}

Danger is an increasingly central phenomenon in the Norwegian criminal justice system. ${ }^{1}$ It is at the heart of retrospective considerations of certain criminalised acts, and may have implications for evaluations of excuses and defences. Danger is also utilised in a prospective sense, in provisions aimed at avoiding feared and unwanted future actions from certain individuals. The Norwegian Penal Code section 62, which regulates the (possibly indefinite) involuntary psychiatric treatment of criminally insane (utilregnelige) offenders, is such a rule. ${ }^{2}$

* Advisor at Haukeland University Hospital, Department of Forensic Psychiatry, Centre for Research and Education. I am indebted to my colleagues at the Centre for Research and Education for the time taken to give valuable feedback on earlier drafts. I have also benefitted from thorough comments from an anonymous reviewer for which I am very grateful.

1 According to Andenæs, The Norwegian Penal Code (LOV-2005-05-20-28 om straff) contains more 'danger delicts' than the previous Penal Code of 1902 (LOV-1902-05-22-10 Almindelig borgerlig straffelov). See Andenæs, Alminnelig strafferett - 6th ed. by Rieber-Mohn and Sæther (Universitetsforlaget 2016), p. 109. 'Danger delicts' (faredelikt) are criminal offences with the central characteristic that the offender is responsible for giving rise to danger of a harmful effect.

2 LOV-2005-05-20-28 om straff. Other examples are the rules regulating remand detention and isolation during remand detention in the Criminal Proceedings Act (LOV-1981-05-2225 om rettergang i straffesaker), section 171 ref. sections 184 and 186 a, and the rule allowing indeterminate sentencing of criminally sane offenders in the Penal Code section 40. 
In governmental proposition $154 \mathrm{~L}$ (2016-2017), the Ministry of Justice and Public Security suggested a revision to the Penal Code section 62. In the proposal, which has now been accepted by the parliament, greater emphasis is placed on the requirement that there is a danger of recurring offences in future cases. ${ }^{3}$ The question of how danger is to be understood is, therefore, key to understanding this provision.

This paper makes a preliminary analysis of the central sources of law in an effort to reveal the meaning of danger in the context of Penal Code section $62 .{ }^{4}$ I will identify several problematic issues which are not resolved in the recent revision. I will argue that the lack of a clear definition of danger and a variance in what dimensions are included in its assessment is apt to cause arbitrariness in the application of the rule. As a result, foreseeing whether or not a criminally insane offender will be subjected to involuntary psychiatric treatment becomes a challenging task.

The paper is organised as follows: section two presents the rule in question and the proposal for revision, section three discusses the legal definitions of the danger requirement, section four analyses factors used in the assessment of danger, section five examines the factual assumptions under which danger assessments are made, and section six draws conclusions from reflections on the findings.

\section{Penal Code Section 62}

\subsection{Overview}

Penal Code section 62 currently contains the following provisions for sentencing offenders to involuntary psychiatric treatment:

'When deemed necessary to protect the life, health or freedom of other persons, an offender who is exempt from punishment pursuant to section 20, letter b) or d), may be sentenced to psychiatric care, see chapter 5 of the Mental Health Care Act, when he has committed or attempted to commit a violent offence, sexual offence, unlawful imprisonment, arson or another offence that has violated the life, health or freedom of another person or could have posed a danger to these legal interests, and the conditions in the second or third paragraphs are met. Committal to psychiatric care, see chapter 5 of the Mental Health Care Act, may also be imposed on an offender who is exempt from punishment pursuant to section 20, b) or d), if he has committed repeat offences that are harmful to society or particularly bothersome, if it is necessary to protect society or other

3 Parliament decision, Lovvedtak 60 (2018-2019) ref. committee recommendation, Innst. 296 L (2018-2019) ref. governmental proposal from the Ministry of Justice and Public Security, Prop. 154 L (2016-2017).

4 The legal sources examined include statutory provisions, legislative preparatory works, legal literature, and a sample of Norwegian Supreme Court verdicts concerning section 39 of the former Penal Code of 1902 and section 62 of the current Penal Code for the period 2003-2017, with excerpts from the preceding High Court verdicts. 
persons against such offences and the conditions in the fourth paragraph are met.

If the offence was of a serious nature, there must be an impending danger that the offender will again commit a serious offence that violates or endangers the life, health or freedom of another person.

If the offence was less serious in nature

a) the offender must previously have committed or attempted to commit a serious offence that violated or endangered the life, health or freedom of another person,

b) there must be a presumption of a close connection between the earlier and the present offence, and

c) the danger of commission of a further serious offence as specified in a) must be particularly impending.

If the offences were harmful to society or particularly bothersome, the danger of further offences of the same type must be particularly impending, and other measures must have proven to be clearly unsuitable.

When assessing the danger of recidivism pursuant to this provision, emphasis shall be put on the committed offence with a particular reference to the offender's conduct, illness development and mental functional capacity.5

As we can see, section 62 contains two types of sanctions. First, a 'serious offences' sanction that is potentially life-long, and secondly, a 'bothersome' sanction that has a limited duration of a maximum of three years.

5 No official translation has been made of the Norwegian Penal Code into English. My own translation here presented differs somewhat from other available translations, which do not, in my view, adequately convey the actual meaning of the terms used in the original:

'Når det anses nødvendig for å verne andres liv, helse eller frihet, kan en lovbryter som er straffri etter $\$ 20$ bokstav b eller bokstavd, ved dom overføres til tvungent psykisk helsevern, jf. psykisk helsevernloven kapittel 5, når han har begått eller forsøkt å begå et voldslovbrudd, et seksuallovbrudd, en frihetsberøvelse, en ildspåsettelse eller et annet lovbrudd som krenket andres liv, helse eller frihet eller kunne utsette disse rettsgodene for fare og vilkårene $i$ annet eller tredje ledd er oppfylt. Overføring til tvungent psykisk helsevern, jf. psykisk helsevernloven kapittel 5, kan også idømmes en lovbryter som er straffri etter $\$ 20$ bokstav b eller bokstav d når han har begått gjentatte lovbrudd av samfunnsskadelig eller sarlig plagsom art, dersom det er nødvendig for å verne samfunnet eller andre borgere mot slike lovbrudd og vilkårene i fjerde ledd er oppfylt.

Var lovbruddet av alvorlig art, må det vore en noerliggende fare for at lovbryteren på nytt vil begå et alvorlig lovbrudd som krenker eller utsetter for fare andres liv, helse eller frihet.

Var lovbruddet av mindre alvorlig art må

a) lovbryteren tidligere ha begått eller forsøkt å begå et alvorlig lovbrudd som krenket eller utsatte for fare andres liv, helse eller frihet,

b) det antas å vore en noer sammenheng mellom det tidligere og det nå begåtte lovbruddet, og

c) faren for tilbakefall til et nytt alvorlig lovbrudd som nevnt $i$ bokstav a, vore sorlig norliggende. Var lovbruddene av samfunnsskadelig eller sarlig plagsom art, må faren for nye lovbrudd av samme art vare sarlig noerliggende, og andre tiltak må ha vist seg åpenbart uhensiktsmessige.

Ved vurderingen av faren for tilbakefall etter bestemmelsen her skal det legges vekt på det begåtte lovbruddet sammenholdt sorlig med lovbryterens atferd, sykdomsutvikling og psykiske funksjonsevne.' 
The 'serious offences' sanction allows involuntary psychiatric treatment of criminally insane offenders who have committed, or attempted to commit, an offence that violates, or poses a danger to individual life, health or freedom. The categories of qualifying index offences (the offence that brought the offender into contact with the criminal justice system) cover a wide range, spanning from homicide to hijacking, cybercrime, aggravated robbery, and threats. ${ }^{6}$

As long as the required threshold for intervention is met, the imposition of these sanctions may be continued. ${ }^{7}$ A case for continuation must, however, be presented to the district court within three years after the last valid verdict. ${ }^{8}$ In addition, the convicted person may request a re-examination of the requirements every twelve months, and the prosecutor's office may lift the sanctions at any time. Both in cases regarding the establishment of sanctions and in cases regarding the continuation of sanctions, it is common that forensic experts make evaluations of the defendant on behalf of the courts, including assessments of whether the defendant poses a risk for violence. ${ }^{9}$

The 'bothersome' sanction is intended for criminally insane offenders who have committed repeat offences considered harmful to society or particularly bothersome. ${ }^{10}$ Frequent offences that violate the integrity or private sphere of citizens are

6 The Ministry's proposal, Prop. 154 L (2016-2017) pp. 123-124, further reference to governmental proposal, Prop. 122 L (2014-2015) p. 35, and governmental proposal, Ot.prp. nr. 90 (2003-2004) p. 459, with further reference to governmental proposal, Ot.prp. nr. 87 (1993-1994) p. 107.

7 See Penal Code section 65.

$8 \quad$ Ibid. For more on the role of the prosecution office, see Holst (2019) 'Court-Ordered Compulsory Psychiatric Care and the Prosecutor's Control Function' Bergen Journal of Criminal Law and Criminal Justice, 7(1) (2019), pp 136-147.

9 The Criminal Proceedings Act, section 165, states that a forensic examination of the defendant must always be performed when considering whether to impose sanctions under section 62 of the Penal Code. Further regulation of the role of expert witnesses is found in the Criminal Proceedings Act chapter 11, where it is stated that: anyone appointed by the Court in principle may not decline the appointment (section 138); unless the Court deems otherwise necessary, there will normally be appointed one expert (section 139); that the involved parties should be given the chance to comment on the choice of expert (section 141); and that the expert may be present during the court proceedings and be allowed to pose questions to the parties, witnesses and other experts (section 144). Although no requirements for formal competency or special authorisation apply, the appointed forensic expert will normally be a private practicing psychiatrist or specialist psychologist, see Molandrapporten (2013) cited in the Ministry's proposal, Prop. L 154 (2016-2017) p. 180.

10 These sanctions were included in a revision of section 62 that came into effect October 2016. Although they may be considered less substantial than the potential life-long measures for the first category, the use of sanctions under the Penal Code for offences generally considered harmful or bothersome has been subject to critique from all related fields including the forensic and legal. Governmental proposition, Prop. 122 L (2014-2015) p. 22, contains a list of negative or sceptical institutions, including the Norwegian Directorate of Health, Helse Bergen, Haukeland University Hospital (Psychiatric Division), Lovisenberg Hospital, the Norwegian University of Science and Technology, Oslo University Hospital HF, Ullevål (Psychiatric division and Regional Security Department), Pro-Legal, the Norwegian Medical Association, the Norwegian Union for Criminal Reform (KROM), and the Norwegian Association for Persons with Intellectual Disabilities. 
the core target, and aggravated theft is, for instance, a qualifying index offence. ${ }^{11}$ Here also, the threshold for intervention must be met if sanctions are to be upheld. ${ }^{12}$ Likewise, assessments of the defendant by forensic experts are common. Under these sanctions, the convicted may request a re-examination every six months. ${ }^{13}$

It has been argued in the literature that the sanctions in section 62 should be reserved for a narrow range of offenders. ${ }^{14}$ This is primarily because the criminally insane are not accountable, and because the sanctions infringe on the 'asylum sovereignty' (asylsuvereniteten) of mental health service institutions, i.e., their exclusive competency to decide whether a patient shall be submitted into care or not. ${ }^{15}$ As of 20 December 2018, 220 persons are serving a sentence under section 62. Out of these, 209 are serving on the grounds of the first category (danger of serious future offences), and 11 on the grounds of the second category (being particularly bothersome to society). ${ }^{16}$

The following discussion focuses on the first category and issues relating to the requirement that there is a danger of future serious offences.

Since the purpose of the provision is societal protection, sanctions under section 62 cannot be established based on a need for treatment, or the need to protect economic interests, alone. ${ }^{17}$ In addition to specifying which offences must have been proven, the rule in section 62 sets two fundamental requirements for the use of involuntary psychiatric treatment: a danger of certain future offences must be present, and the use of such a sanction must be deemed necessary to protect society.

In an earlier governmental proposal, which forms the basis for the current rule, the legislator explains that protective necessity is the basic condition for the application of the sanction. ${ }^{18}$ Hence, whether or not there is a danger is an element in the evaluation of whether the basic condition is met:

11 HR-2017-2249-A.

12 See Penal Code section 65.

13 Ibid.

14 Gröning et al, Frihet, forbrytelse og straff - En systematisk fremstilling av norsk strafferett (Fagbokforlaget 2016) pp. 652-653, and Jacobsen, Dom på overføring til tvungent psykisk helsevern - Straffeloven $\$ 39$ (Fagbokforlaget 2004) pp. 50-51.

15 Gröning et al. (2016) pp. 652-653, and Jacobsen (2004) pp. 50-51. On the meaning of the term, 'asylum sovereignty', see, for instance, Sandberg, 'Asylsuvereniteten, Rett og urett', Tidsskriftet den norske legeforening, 10 (2001) p. 1287. For more on the respective roles of the prosecution service and the mental health care institution during the commitment, see Holst (2019).

16 Numbers provided by the National Coordination Unit for Penal Sanctions on Compulsory Psychiatric Care, in a personal e-mail to the author.

17 The Ministry's proposal, Prop 154 L (2016-2017) p. 123 and Gröning et al. (2016) p. 652, with further reference to Matningsdal, Straffeloven: lov 20. Mai $2005 \mathrm{nr} 28$ om straff: alminnelige bestemmelser: kommentarutgave (Gyldendal 2015) p. 583. 
'[Necessity] deals with the basic condition for the use of sanctions under section 62. The sanction must be considered necessary to protect society. The court must make a discretionary assessment of whether sanctions under section 62 should be applied. Relevant factors in the assessment are the seriousness of the crime committed, the probability/likelihood 19 of repeat offences, the seriousness of the feared offence and the offender's mental state. It must also be taken into consideration what society has to offer the offender apart from sanctions under section 62, e.g., through the Mental Health Care Act. ${ }^{20}$

In later preparatory works, the legislator emphasises necessity and danger as separate requirements. ${ }^{21}$ According to the legislator, the courts have, contrary to this, dealt with both danger and necessity in an overall assessment. This is considered unfortunate, as, in the legislator's view, there might occur situations where a sufficient danger is present but where the use of involuntary psychiatric treatment is not necessary. ${ }^{22}$ For instance, where the perceived danger is sufficiently managed through voluntary or involuntary civil psychiatric treatment measures already in place at the time of the judgement, or where the mental state of the offender has changed. ${ }^{23}$

As will become clearer in the analysis of the Supreme Court cases in section 5 below, the different views on the relationship between the danger and necessity requirements might be representative of a somewhat different interpretation of the rule's legal meaning. Among the possible legal interpretations, a main division can perhaps be made between a rule that includes the temporal dimension, the current treatment regime, and the offender's current mental state in the danger assessment, and a rule that locates such factors in the necessity assessment.

The latter alternative arguably presupposes that danger is something that can be established isolated from the offender's actual and/or expected future situation at the time of the judgement. Conversely, in the former alternative, the offender's situation will be highly relevant for the assessment of danger. How one interprets the legal meaning of danger can in this way influence the final outcome, as may be illustrated with the Supreme Court case Rt. 2006 p. 1143 . Here, a sufficient treatment regime in which the offender was already enrolled led to a negative conclusion on the danger requirement, making a necessity evaluation superfluous. ${ }^{24}$

Furthermore, a relative threshold for intervention is discussed in the preparatory works, where the question of whether danger is present is seen as dependent both

19 The Norwegian word sannsynlig is the applied term. It covers both probability and likelihood. As a result, it can be hard to tell which one is meant, and I have therefore included both.

20 The author's translation from governmental proposal, Ot.prp. nr. 87 (1993-1994) p. 106. Some minor alterations in the translated text have been made for the purpose of semantic clarification.

21 See, for instance, governmental proposal, Prop. 122 L (2014-2015) pp. 35-40, where available alternative measures are still seen as part of the necessity evaluation.

22 Governmental proposal, Prop. 122 L (2014-2015) p. 40.

23 Governmental proposal, Ot.prp. nr. 87 (1993-1994) p. 106, and governmental proposal, Prop. 122 L (2014-2015) p. 40.

24 See section 5 below. 
on the seriousness of the committed offence and on the seriousness of potential future offences. ${ }^{25}$ Only the former was, however, included in the rule itself. Section 62 requires an 'impending danger' if the committed offence was serious, and a 'particularly impending danger' if the committed offence was less serious. For the less serious offences, a previous offence or attempted offence that violated or endangered the life, health or freedom of others, and a presumption of a close connection between the earlier and present offence, form additional requirements, as stated in section 62 third paragraph, letters a and b. ${ }^{26}$ A proposal to change this has now been accepted.

\subsection{Accepted Revision}

In the aftermath of the 22 July terrorist attacks, a committee was tasked with investigating the need for legislative change to the rules on criminal insanity (utilregnelighet) and related issues. The resulting report, NOU 2014: 10, criticised the differentiation in section 62 between earlier serious and less serious criminal offences, and suggested its removal. ${ }^{27}$ So also the requirement of a previous serious violation. ${ }^{28}$ It pointed out that the purpose of section 62 is to secure such legal values as the life, health and freedom of others for the future, and that the threat posed to these values is not necessarily dependent on the seriousness of the offence that has already been committed. Rather, the report argued that the 'level of danger required should be higher when the value at stake is of relatively lower importance, but should be markedly lower when a particularly significant value, such as life, is threatened, for example where there is a risk of murder. ${ }^{29}$

In governmental proposition $154 \mathrm{~L}$ (2016-2017), the Ministry of Justice and Public Security proposed to follow the committee's advice for such a revision of section 62. More specifically, the Ministry suggested the requirement be formulated as a demand that the sanctions are necessary for the protection of society, and that the danger of a new and serious integrity violation is impending. ${ }^{30}$ This danger shall be assessed

$25 \quad$ Governmental proposal, Ot.prp. nr. 87 (1993-1994) p. 108.

26 In establishing whether a previous offence has taken place, the legislator assumes that it essentially will be required to apply the same standard of evidence as for a criminal conviction - in dubio pro reo. See governmental proposal, Ot.prp. nr. 87 (1993-1994) p.107. So also in legal theory and jurisprudence, e.g., Jacobsen (2004) p. 126 onwards, and Matningsdal, The Penal Code commentary (Gyldendal 2018), https://min.rettsdata.no/Dokument/gL20050520z2D28 (last accessed $9^{\text {th }}$ September 2019), note 477 and 279, with further reference to Supreme Court verdicts Rt. 2004 p. 209, Rt. 2004 p. 606 and Rt. 2004 p. 1953. In the evaluation of other circumstances, the required standard of evidence has been considered somewhat lower; see Jacobsen (2004) pp. 119 onwards.

27 Gröning and Rieber-Mohn, 'Proposal for New Rules Regarding Criminal Insanity and Related Issues, Norway post-22 July', Bergen Journal of Criminal Law \& Criminal Justice 3(1) (2015) pp. 126-127.

$28 \quad$ Idem., p. 127.

29 Ibid.

$30 \quad$ The Ministry's proposal, Prop. 154 L (2016-2017) p. 236. 
independently of the seriousness of the index crime, but relative to the seriousness of the feared crime. ${ }^{31}$ As acknowledged by the Ministry, this will entail a shift in the courts' assessment of danger from the previous emphasis on what the offender has done to the more uncertain question of what the offender might do. ${ }^{32}$ The question then arises as to how the legislator has intended the courts to deal with this increasing uncertainty. As we shall see, general legal principles may entail some constraints.

Leaving the decision on who is to be detained in psychiatric institutions entirely up to the courts' discretion would certainly relieve the legislator of much difficulty. Constructing a rule that allows the courts to detain whoever the courts believe to be dangerous does not raise many technical legal issues, as a mere reference to danger could be sufficient to communicate what it is the court is asked to do. Such a rule would, however, leave the door open for mere speculation and value judgements, that, in light of rule-of-law values such as legal clarity, legal predictability, and equality before the law, could be considered problematic. ${ }^{33}$

The opposite approach, which from a legislative perspective is more demanding, is to limit the courts' discretion by setting requirements for what is legally relevant to take into consideration, and thus increase the foreseeability of the application of the rule. This would not necessarily exclude discretionary assessments altogether, but it could provide a framework for the courts' exercise of discretion, and thereby bring the application of the law closer to the ideal-that different judges, when presented with the same case, would examine the same evidentiary topics and hopefully reach the same conclusions.

How the section 62 rule fits in with this illustrative dichotomy will largely depend on what requirements the criterion of impending danger actually creates for the legal decision maker's assessment. In the following three sections, we shall examine this closer.

\section{Defining the Danger Requirement}

\subsection{What is an 'Impending Danger'?}

What is the meaning of an impending danger? At least three interrelated challenges arise in an attempt at an answer. First, it must be further explained what concept im-

31 The Ministry's proposal, Prop. 154 L (2016-2017) pp. 134-141.

32 Ibid.

33 For a disquieting illustration of such value judgements, see Ashworth and Zedner, Preventive Justice (Oxford University Press 2014) p. 141. See also p. 113 on the general rule-of-law principle of clarity. Furthermore, the Norwegian Constitution section 96 is interpreted to contain a clarity requirement, thus placing this principle at a constitutional level in Norway, see, among others, Gröning et al. (2016) p. 68 onwards. 
pending danger is intended to convey semantically. Secondly, it must be established how this phenomenon is to be identified, that is, based on what criteria it is to be assessed. Thirdly, it must be determined which factual assumptions this assessment should be based on. In the next sections, we shall examine how the legislator, legal theory and the Supreme Court might have shed light on this three-piece puzzle.

\subsection{Semantic Meaning}

The Ministry of Justice and Public Security has in the new proposal made use of an earlier definition of 'impending danger of a future offence' as 'a sufficient degree of risk for recidivism, and the danger must at the time of the judgement be considered real. ${ }^{34}$ This definition has been a matter of debate in legal theory. It has, for instance, been characterised as a tautology and criticised for not providing any further clarifications of its meaning. ${ }^{35}$ Considering that the term risk-arguably more so in Norwegian than in English-bears close semantic resemblance to the term danger, this critique, at least prima facie, seems warranted. Looking to the variance in applied definitions in verdicts, this is no less so.

In a Supreme Court verdict from 2003, the definition of impending danger as a sufficient degree of risk for recidivism and a danger that at the time of the verdict must be considered real, is referenced. ${ }^{36}$ Pointing to the verdict from 2003, the Supreme Court in 2004 also uses this definition. ${ }^{37}$ In 2005 the use of risk is abandoned and replaced with a new formulation stating that the danger of recidivism must be sufficient and real, and that the requisite severity of danger can vary depending on the seriousness of the committed crime. ${ }^{38}$ In 2006 the new definition from 2005 is used. ${ }^{39}$ In a second verdict from 2006, the risk definition from 2003 is again referenced. ${ }^{40}$ In 2010 there is no mention of risk at all. ${ }^{41}$ In 2011 reference is made to the latter definition from the verdicts in 2006 with one alteration: the risk element is not included. ${ }^{42}$ In the latest Supreme Court verdict there is no mention of risk, reference is still

34 The Ministry's proposal, Prop. 154 L (2016-2017) p. 141. This is the same definition as the one presented in governmental proposal, Ot.prp. nr. 87 (1993-1994) p. 108.

35 Syse, 'Dømt til behandling - frikjent til fengsel. Nye strafferettslige ansvarsregler og særreaksjoner', Nytt i strafferetten 1 (1997) p. 49 and Jacobsen (2004) p. 109 with further reference to governmental proposal, Ot.prp. nr. 87 (1993-1994) p. 108 and commission report, NOU 1990:5 p. 86.

$36 \quad$ Rt. 2003 p. 1085.

$37 \quad$ Rt. 2004 p. 1119.

$38 \quad$ Rt. 2005 p. 1091.

$39 \quad$ Rt. 2006 p. 1137.

$40 \quad$ Ibid, p. 1143.

$41 \quad$ Rt. 2010 p. 346.

$42 \quad$ Rt. 2011 p. 385. 
made to the second verdict from 2006, and a sufficient danger of recidivism is the applied clarification. ${ }^{43}$ A synonymous use of risk and danger thus seems to be taking place without clear definitions of how these phenomena are to be understood in the context of Penal Code section 62. As a result, the Supreme Court does not seem to escape the above-mentioned critique.

The question regarding which criteria one is dealing with has also been given variable attention in the legal literature. In contrast to seemingly highly prevalent debates on the topic within the common law jurisdictions, and despite the obvious relevance of danger, the actual legal conceptual contents of this phenomenon have, until recently, received minimal attention in Norwegian legal literature. ${ }^{44} \mathrm{~A}$ symptomatic illustration is the thorough description of the danger assessment given in Matningsdal's commentary to the Penal Code, but where no further specification is made of the phenomena this assessment is intended to reveal. ${ }^{45}$

There are, however, exceptions, and a renewed interest in the danger phenomenon has given rise to several alternative definitions of danger more generally, which can serve as a basis for a discussion on the contents of danger specifically in the context of Penal Code section 62.

In his commentary on the former Penal Code section 39 (which the current Penal Code section 62 upholds) Jacobsen, for instance, discusses danger to a greater degree and states (by referring to Jareborg) that danger can be understood as a possibility that something considered negative will happen. ${ }^{46}$ Danger is thus seen as an expression of a possibility-relation between one or more causal factors and the possible negative outcome. ${ }^{47}$ Impending is explained as a threshold for how probable/likely

43 HR-2017-2249-A.

44 See Floud, 'Dangeorusness and Criminal Justice', The British Journal of Criminology, 22(3) (1982) pp. 213-228; Bottoms and Brownsword, 'Dangerousness and Rights', in J.W. Hinton (ed.) Dangerousness: Problems of Assessment and Prediction (George Allen \& Unwin Ltd. 1983); Pratt, Governing the Dangerous (The Federation Press 1997); Slobogin, A Jurisprudence of Dangerousness', Northwestern University Law Review 98(1) (2003); Ashworth and Roberts, 'Sentencing: Theory, Principle and Practice', in The Oxford Handbook of Criminology, Fifth Edition (Oxford University Press 2012) pp. 888-890; and Ashworth and Zedner (2014). On the lacking discussion in Norwegian legal literature, see Gröning et al. (2016) p. 180, and Boucht, 'Politirettslig fare - særlig ved ordensforstyrrelser', Tidsskrift for strafferett 4 (2018) p. 333.

$45 \quad$ Matningsdal (2015) pp. 582-593. Similarly, the concept of danger delicts is explained in several Norwegian standard works on criminal law without danger as a phenomenon being defined. See, for instance, Matningsdal, Norsk spesiell strafferett (Fagbokforlaget 2010) p. 5. So also in Mæland, Norsk alminnelig strafferett (Justian AS 2012) p. 56. Somewhat more is said in Andenæs (2016) pp. 109 and 347, where in relation to danger delicts it is explained that the manifestation of a danger as an adequate result of the action is sufficient. Eskeland, Strafferett - 5th ed., by Alf Petter Høgberg (Cappelen Damm 2017) p. 195 explains that danger delicts often entail a requirement of the danger being induced in a certain way in addition to this behaviour being the cause of the danger.

46 Jacobsen (2004) p. 101.

47 Ibid. 
the danger must be, something that, according to Jacobsen, can hardly be assessed without taking the same elements as in the danger assessment into consideration. ${ }^{48}$

Similar definitions may also be found in discussions on adjoining topics such as the Penal Code provisions that criminalise actions which give rise to danger (danger delicts) and in police law. In a standard work on criminal law, Gröning et al. explain how danger in earlier Norwegian literature has been defined as 'an impending possibility for a destructive effect' and in Swedish legal literature as a demand that damage is 'existentially possible' and 'plausible', plausible meaning reasonable to expect rather than mathematically probable. ${ }^{49}$ Their own view is that danger in the context of danger delicts is a situation that:

'1. the offender has induced through a prior action,

2. is outside the offender's control, and

3. involves a possibility for damage. ${ }^{50}$

Løvlie also seems to see danger as a possibility-relation:

'A claim about danger inducement presupposes experience-based inferring linked to three conditions. Firstly, experiences needed to decide about claims regarding the behaviour specified as dangerous. Secondly, experiences regarding the behaviour's possibility to damage protected legal values, often expressed as probability/likelihood. [...] Whether the behaviour is dangerous can furthermore not be assessed in isolation, but expresses that one possible connection between phenomena is isolated, here behaviour and legal values, at the same time as other conditions are presupposed. [...] It will depend on constituting criteria what conditions may be presupposed. ${ }^{51}$

In a policing context danger is, according to Auglend and Mæland, understood as:

'actual actions or conditions that, after an objective assessment and according to 'the general rules of life', must be supposed will develop to an infringement of a politirettslig [police-legal] protected interest if the action or condition is allowed to continue unaffected.52

And consisting of three elements:

48 Idem. pp. 123-125 and pp. 107-108. A similar understanding of impending is expressed in relation to similar requirements in other legislation. See for instance Syse, Psykisk helsevernloven - med kommentarer (Gyldendal 2004) p. 130 on the requirement for civil commitment under the Mental Health Care Act (LOV-1999-07-02-62 om etablering og gjennomføring av psykisk helsevern) section 3-3 and Øyen, 'Varetektsfengsling ved bevisforspillelsesfare', Jussens venner, 4 (2010) pp. 226-227 on a similar requirement for remand detention in the Criminal Proceedings Act section 182 ref. section 171 number 2.

49 Gröning et al. (2016) pp. 180-181 with further reference Asp et al., Kriminalrättens grunder 2nd ed. (Iustus 2013) p. 93. The author's translation.

50 Idem. p. 181. The author's translation.

51 Løvlie, Rettslige faktabegreper (Gyldendal 2014) pp. 160-161 with further reference to Andenæs and Goodman. The author's translation.

52 Auglend and Mæland, Politirett (Gyldendal 2016) p. 411, with further reference to Sjöholm and Henricson. The author's translation. 
(1) objective situational facts, (2) a requirement of an experience-based probability/likelihood and (3) the potential infringement object must be considered among the interests that are awarded politirettslig [police-legal] protection. ${ }^{53}$

In a recent paper based on a review of Nordic and German legal literature, Boucht argues that danger in a police-legal context, on a general level can be understood as a 'state where a certain identified circumstance gives rise to a risk directed towards a politirettslig [police-legal] protected interest, that exceeds the commonly accepted risk, but where damage has not yet occurred. ${ }^{54}$ Furthermore, he argues that there are good reasons to support a view of the police-legal danger concept as 'saksforhold [circumstances of a case] that, if not prevented, will result in an objective course of events that, with sufficient probability/likelihood, is expected to entail an infringement of a polisioer [police-legal] protected interest. ${ }^{35}$ However, after having discussed different dimensions of the politirettslige (police-legal) danger concept, he arrives at the conclusion that danger in this context can be summarised as:

saksforhold [circumstances of a case] that in a concrete situation, after a reasonable assessment ex ante from a normally cautious policeman's perspective, gives reasonable grounds to believe that it will result in an infringement of a politirettslig [police-legal] protected interest within the foreseeable future..$^{56}$

It is here worth noting, that Boucht's definition of danger, unlike the others, includes a specification of the time-perspective. ${ }^{57}$

\subsection{Provisional Definition}

Based on these definitions, we can construct four preliminary definitions of danger in the context of Penal Code section 62:

1. Danger is a situation or state that creates a possibility for serious future offences.

2. Danger is a situation or state that makes future serious offences plausible.

3. Danger is a situation or state that makes future serious offences probable/likely.

4. Danger is a situation or state that creates sufficient risk that a serious future offence will occur.

As we can see, while definitions one to three operate on the different modalities possibility, plausibility and probability/likelihood, definition four requires the determi-

53 Ibid

54 Boucht (2018). The author's translation.

55 Ibid.

56 Ibid.

57 See the discussion on factual assumptions in section 5 below. 
nation of a sufficient risk. Depending on the meaning attached to the alternatives, it is not immaterial which definition forms the basis for the rule. One could, for instance, argue that it would take less to establish a fact as possible, rather than plausible-let alone probable. In this way, the danger definition may directly influence which threshold applies. Unless further specified, a reference to danger, therefore, does not-at least in itself-constitute a clear framework for the danger assessment.

The picture is further complicated when these alternative definitions are combined with the previously described legal meaning of the term impending, i.e., as a threshold for how probable/likely the danger must be. Then, a somewhat confusing situation arises, where a probability/possibility assessment features twice in the assessment of an impending danger. The rule seemingly requires the assessment of the probability/likelihood of what has itself already been defined as a possibility, plausibility, probability/likelihood, or sufficient risk for a future offence.

If we let the probability/likelihood threshold implied by impending consume the middle element (i.e., the possibility assessment contained within the definition of danger), this issue can be solved:

5. Impending danger is a sufficient probability/likelihood that a situation or state will result in serious future offences.

On a deeper level, this definition also might be considered ambiguous, as it does not make clear what kind of probability/likelihood, for instance within the dichotomy of objective and subjective probabilities, must be established for an impending danger to be considered present. ${ }^{58}$ Within the scope of this paper, this seems to be as close to a proposal for a semantically clear definition of danger as we can get. However, returning to the legislator and Supreme Court's attempted definitions, another issue arises with the potential to capsize this attempt at further clarity altogether, that is, how are we to understand the many references to risk?

\subsection{What is a 'Sufficient Risk'?}

As seen in subsection 3.2, the requirement of impending danger has been defined by the legislator as a sufficient risk and a synonymous use of the terms risk and danger apparently takes place in Supreme Court verdicts. In the assessment of the requirements, the verdicts sometimes take a risk-based starting point and other times a danger-based starting point. But are the concepts of danger and risk really synonymous?

58 See for instance, Aven and Reniers, 'How to define and interpret a probability in a risk and safety setting', Safety Science 51 (2013) pp. 223-231, and Taroni et al. 'Reconciliation of Subjective Probabilities and Frequencies in Forensic Science', Law, Probability and Risk, 17(3) (2018) pp. 243-262. This is a topic for another discussion. Although acknowledging the issue, a continued reference to probability/likelihood, without further specification of which type, will therefore follow. 
If so, would this entail that the term risk here points to the same phenomenon as has been defined by the concept of danger? If not, it could mean that different phenomena form the requirement for intervention in different cases. Yet another possibility is that risk, in some way, is involved as a criterion in a wider definition of danger as implied in the alternative definition four above.

In their discussion on the concept of danger in the context of danger delicts, Gröning et al. (2016) argue that a distinction between danger and risk can be made based on the point of loss of control. ${ }^{59}$ This means that risk is connected to a situation where the offender has not yet committed an initiating act, and danger to a situation where the initiating act has been committed, and the outcome is out of the offender's control. ${ }^{60} \mathrm{~A}$ similar distinction is made by Auglend and Mæland. ${ }^{61}$ Risk is, however, also a term with several possible meanings. Due to a growing ambiguity, it is not obvious what is actually meant whenever the term risk is used. This is particularly evident when considering how risk is defined across different settings.

After its introduction in the mid-1970s, a definition of risk as a statistical expectation value for unwanted events determined through the product of probability and severity has become the standard technical meaning of the term in many disciplines such as engineering, professional risk analysis and nuclear energy safety. ${ }^{62}$ However, as for instance shown by Hansson, acceptable uses of the term risk in technical settings also include:

$$
\begin{aligned}
& \text { '[...] risk = an unwanted event which may or may not occur. }[\ldots] \text { risk }=\text { the cause of an } \\
& \text { unwanted event which may or may not occur. [...] risk }=\text { the probability of an unwanted } \\
& \text { event which may or may not occur. [...] risk }=\text { the fact that a decision is made under } \\
& \text { conditions of known probabilities ('decision under risk' as opposed to 'decision under un- } \\
& \text { certainty') [...].63 }
\end{aligned}
$$

In security settings, e.g., terrorist attack prevention, a contextual definition with the threefold assessment criteria of asset/value, threat and vulnerability is common. ${ }^{64}$ For the risk management setting, the International Standardization Organization's current guidelines (revised in 2018) defines risk as the 'effect of uncertainty on objectives. ${ }^{65}$ In the forensic psychiatry setting, risk has been defined as a multidimensional

59 Gröning et al. (2016) p. 181-182.

60 Ibid.

$61 \quad$ Auglend and Mæland (2016) pp. 410 onwards.

62 Hansson, Risk, Stanford Encyclopedia of Philosophy Archive (2018), with further references to Rasmussen et al. (1975) and Rechard (1999); Hansson, 'Philosophical Perspectives On Risk', Techné 8(1) (2004) pp. 10-35; and Lowrance, Of acceptable risk: science and the determination of safety (William Kaufmann 1976).

63 Hansson (2018).

64 Amundrud et al., 'How the definition of security risk can be made compatible with safety definitions', Proc IMechE Part O: J Risk and Reliability 231(3) (2017) pp. 286-294.

65 ISO 31000:2018 
entity specified as 'a hazard that is incompletely understood, and thus its occurrence can be forecast only with uncertainty. ${ }^{3}$

In Norwegian legal literature, however, the classical technical definition of risk, as a function of probability/likelihood and consequences/severity, appears to be the leading candidate. ${ }^{67}$ This would suggest that when a danger requirement is defined in terms of risk, it is something that can be measured in terms of probability/likelihood $(\mathrm{P})$ and consequences $(\mathrm{C})$. This being so, when comparing the concept of danger to the traditional definitions of risk as a function of $(\mathrm{P})$ and $(\mathrm{C})$, it is still not obvious that the concepts here implied are identical.

Nevertheless, it is possible to use sufficient risk and impending danger in a synonymous way. (C) could be seen as referring to the feared serious future offences. Then (P) would have to cover both the situation/state element, the possibility-element, and the probability/likelihood that the situation/state will cause future serious offences. Sufficient might then be seen as a specification of how probable/likely the manifestation of this possibility must be for sufficient risk to be present. This indicates that risk is not compatible with the first and second danger definitions on its own, because, contrary to these definitions, risk implies a probability/likelihood assessment in itself.

A sufficient risk, and an impending danger may, however, entail the same phenomena if the suggested danger definition is applied and the (P)-element and sufficient are understood in the way described above. Depending on how danger and risk are defined, a synonymous use of the terms might thus take place without necessarily changing the actual contents of the phenomena being assessed. Whether the legislator and the Supreme Court actually have done so, is another question. As neither has provided a clear definition of what danger is supposed to entail, or how risk is supposed to fit in, this remains uncertain.

\subsection{Preliminary Conclusion}

It falls outside the scope of this paper to provide a full account of the different ways in which the phenomena of danger and risk can be defined. The discussion has so far nonetheless illustrated a lack of clarity caused by the legislator's failure to pro-

66 Hart, 'Evidence-Based Assessment of Risk for Sexual Violence', Chapman Journal of Criminal Justice Vol. 1 (2009) pp. 143-165. Similar in Douglas et al. HCR-20 v3 - Assessing Risk for Violence (Mental Health, Law and Policy Institute, Simon Fraser University 2013).

67 See Auglend and Mæland (2016) pp. 415-416 and Horn, Fullstendig isolasjon - ved risiko for bevisforspillelsesfare (Fagbokforlaget 2017) p. 307, with further reference to Strandberg, M. Beviskrav I sivile saker - en bevisteoretisk studie av den norske beviskravslorens forutsetninger (2012) p. 133; Søvig, Tvang overfor rusmiddelavhengige - sosialtjenesteloven \$\$ 6-2 til 6-3 (2007) pp. 268-269; Zahle, Om det juridiske bevis (1976) p. 195; Hjort, Tilgang til bevis i sivile saker sarlig om digitale bevis (2015) pp. 223-224. 
vide a clear definition, as well as some problematic aspects of an uncritical synonymous use of the terms danger and risk. In light of the several possible meanings implied by these terms, the requirement of impending danger may not be as clear as the rule might lead one to believe at first impression. What actual framework this requirement provides for the court's discretion, and to what degree the values of legal equality, predictability and clarity are upheld, is, therefore, at least up for debate. The Ministry's intended shift towards a greater emphasis on the danger requirement can be expected to further increase the effects of any lack of clarity, thus jeopardising the mentioned rule-of-law values. Further efforts should therefore be made to solve these issues.

The definition is, however, only part of the picture. The danger requirement may also frame the danger assessment by providing directions for how this phenomenon is to be identified. In Penal Code section 62, this has been done by specifying certain elements thought to be indicative of danger that are to be taken into consideration. A closer look at these might settle any worries about arbitrariness in the application of the rule.

\section{Indications of Danger}

As we have discussed above, an assessment of danger, at least when danger is understood in a certain way, may be said to include the determination of the presence of a situation or state that is considered to stand in some form of possibility relation to the feared consequences. Whether a particular person, at a particular time, is considered to pose a danger or not may, if the suggested clarification of the definition is accepted, to a large degree depend on what situation or state is considered to bring about the possibility of damage to the protected legal values. ${ }^{68}$ In Penal Code section 62, directions for the relevant situation or state have been provided in the last sentence. It is here stated that in the danger assessment, 'emphasis shall be put on the committed offence with a particular reference to the offender's conduct, illness development and mental functional capacity.' A closer examination of these indications follows.

The legislator has acknowledged that it is impossible to achieve certainty that an offender will commit future offences if the special sanctions are not imposed, and that assessments of danger are encumbered with uncertainty. ${ }^{69}$ It has, however, also been presupposed that 'dangerousness' might be established to such a degree of probability/likelihood that the consideration of society's need for protection can outfootnote 51 .

69 The Ministry's proposal, Prop. 154 L (2016-2017) p. 135 and governmental proposal, Ot.prp. nr. 87 (1993-1994) p. 60. 
weigh the consideration of the individual. ${ }^{70}$ Although assessment of danger of future offences is not considered an exact science, in the case of criminally insane offenders, it is believed that there are relatively good indications on which a danger assessment can be made. ${ }^{71}$

When examining these indications, that is, the criteria for the danger assessment in the final sentence of section 62, it is evident from the chosen words alone that the legislator has considered certain categories of criminal acts as fundamental in establishing the danger of future criminal behaviour. This has been confirmed in earlier preparatory works, where it is stated that the committed offence forms the basis for the danger assessment, and that the scope and nature of this offence may provide insight into the probability/likelihood that the offender will commit another similar offence. ${ }^{72}$ The view that an offender's record of previous offences is an important factor in the consideration of what danger is present in the future, is upheld in the proposal for revision. ${ }^{73}$ However, it is also emphasised that there is no automatic relation between criminally insane offenders committing one integrity violation and the occurrence of future integrity violations. ${ }^{74}$ Therefore, section 62 will continue to require that the following additional criteria are taken into consideration: the offender's conduct, the illness development, their mental functional capacity, with the addition-the offender's relationship to drugs.

According to the legislator, conduct is to be understood as the behaviour both before and after the committed offence. ${ }^{75}$ Whether the offender has expressed other aggressive or criminal behaviour than the offence currently in question has been considered of special interest. ${ }^{76}$ Furthermore, it has been assumed that earlier violent behaviour strengthens the prediction of the danger of future offences, compared to cases where the offence in question is the offender's first violent act. ${ }^{77}$ However, it is also pointed out that 'dangerousness' might be established already after one serious offence.

Illness development could be understood as referring to the illness that gave rise to the exemption from criminal liability. It has been assumed that, in certain cases, there will be a causal link between this illness and the defendant's 'dangerousness.' ${ }^{78}$ The expected illness prognosis is therefore also relevant to the assessment of the dan-

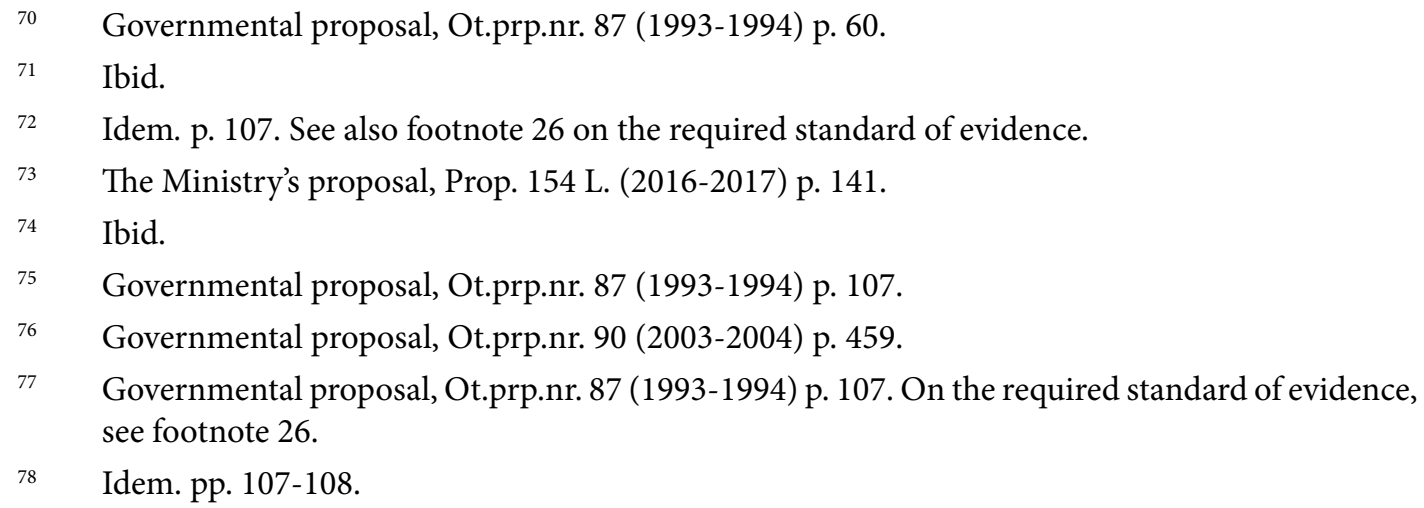


ger of recidivism. ${ }^{79}$

The factor mental functional capacity is, according to the legislator, primarily aimed at mentally disabled offenders, but also for the mentally ill it is considered important to evaluate self-care ability, insight into the illness, and relationship with the outside world. ${ }^{80}$

The reason given for the proposed inclusion of the additional factor of relationship to drugs, is that experience supposedly has shown that substance use increases the risk for violence. ${ }^{81}$

At least two of these factors, illness development and mental functional capacity, concern the mental health of the offender. An application of the rule in accordance with the legislator's intentions thereby requires that the jurist enter into a discipline usually occupied by other professions, employing specialist knowledge that neither the prosecution service nor the courts normally possess. ${ }^{82} \mathrm{~A}$ well-known solution is to bring the other professions into the legal domain using court appointed forensic experts. However, as mentioned in subsection 2.1, the forensic experts' contribution is in practice not limited to an evaluation of these factors, but often also includes an assessment of the risk for violence. A glance at these contributions gives cause to worry about reliability.

As of 2001, the Psychiatry Group of the Norwegian Board of Forensic Medicine ${ }^{83}$ has recommended the use of a structured profession judgement approach (SPJ) to violence risk assessments. ${ }^{84}$ Even though risk of future violence is a topic of concern

79 Governmental proposal, Ot.prp.nr.90 (2003-2004) p. 459.

$80 \quad$ Ibid.

81 The Ministry's proposal, Prop. 154 L (2016-2017) p. 232.

82 Gröning and Rieber-Mohn (2015) p. 123.

83 Whose tasks include training of forensic experts and review and quality assurance of the forensic expert reports submitted to the prosecution services and courts.

$84 \quad$ See The Norwegian Board of Forensic Medicine, Psychiatry Group's newsletter no. 5 (2001) and onwards. The SPJ approach is characterised by the use of validated instruments to structure the experts' assessment in regard to: the types of information that should be gathered; the standard set of risk factors to be considered; instructions for rating risk factors; guidance for making final risk judgments based on the relevance of the risk factors and the need for interventions; and the facilitation of risk management. The commonly used instruments are directly informed by both the scientific and professional literature, and the risk factors selected include dynamic risk factors that are necessary to engage in treatment and risk management planning. The applied structure separates this approach from the purely discretionary clinical judgement approaches sometimes characterised as 'informal, subjective, [and] impressionistic'. Ref. Grove and Meehl, 'Comparative efficiency of informal (subjective, impressionistic) and formal (mechanical, algorithmic) prediction procedures: The clinical-statistical controversy'. Psychology, Public Policy, and Law, 2(2) (1996) pp. 293-323. The prevention focus and the degree of professional judgment exercised by the expert separates it from the typical actuarial approaches that are designed to generate a prediction of future violence within a specified population using algorithms for the weighing and combining of empirically selected risk factors. 
that the court appointed experts have expressed their opinion about in several of the Norwegian Supreme Court verdicts in our sample, no reference to the SPJ-approach could be found. One can therefore not help but wonder if there is a variation in the nature and quality of the experts' contributions. Considering the material from the experts' assessments to which the High Court has chosen to refer in verdicts underlying the Supreme Court cases in this analysis, and where reference to the SPJ-instrument HCR-20 $0^{85}$ is made, it seems so.

In LG-2010-114466 ${ }^{86}$, the High Court, for instance, reference an actuarial risk-assessment done with the use of the HCR-20:

'The result in the HCR-20 assessment was a score of 20 out of 40, compared to 25 out of 40 in 2006. The experts have in their comments to the test score explained that a reduced score indicates a lower degree of dangerousness, but have at the same time specified that this reduced score assumes that the current treatment regime is upheld.'

In LF-2006-27331 ${ }^{87}$ the forensic expert, on a basis of the HCR-20, expressed the risk perceived with different scenarios:

'The forensic experts have, in the additional report regarding the question of danger of repeated offences, pointed to the forensic expert report of 5 February 2005, where it is stated:

"In regard to the prognosis for danger of repeated offences, the forensic experts point to the HCR-20. The Subject has a relatively high score on historical data, and also on clinical data. If he were to be discharged without the possibility of treatment or follow-up, he will also receive a high score for risk for recurrence of criminal offences in the future.

The conclusion is, therefore, that if the Subject is discharged to his own residence without an outer framework, there will be a significant risk for recurrence of criminal offences, both such criminal offences of which he is convicted and actions that he has admitted.

With structured follow-up and treatment, in addition to a meaningful daily life, this risk will be considered reduced to medium."

During the appeal proceedings the forensic experts have clarified that significant risk as used above is to be understood as high risk, ref. that the used classification system HCR20 groups the danger of recurring offences as high, medium or low. The forensic experts furthermore expressed that the presupposition of a meaningful daily life is considerably subjective and-thus implied-possibly difficult to realise for a person with A's diagnosis.'

Webster et al., HCR-20 Assessing Risk for Violence version 2 (Mental Health, Law and Policy Institute, Simon Fraser University 1997), Douglas et al. (2013), and Norwegian translation by Hoff et al. HCR-20 v3 - Voldsrisikovurdering (Helse Bergen HF 2013). According to Bjørkly et al., 'Norwegian Developments and Perspectives on Violence Risk Assessment', Criminal Justice and Behaviour 41(12) (2014) p. 1391, the HCR-20 is the leading tool for violence risk assessment in Norway.

86 Appealed to the Supreme Court and tried in verdict Rt. 2011 p. 385.

87 Appealed to the Supreme Court and tried in verdict Rt. 2006 p. 1143 
In LB-2005-12926 ${ }^{88}$, the main goal of the HCR-20 appears to be a categorising of perceived risk in the absence of medication:

'The forensic experts in the autumn of 2004 made an assessment to predict the risk for future violence. The conclusion of this HCR-20 assessment is that, at this time, there was a considerably high risk that $A$ would commit new aggressive actions against persons in the community.

In the conclusion of the forensic evaluation it is, among other things, stated that:

"The prerequisite for an optimal prognosis where the risk for new violent acts is minimal, is that the Subject is treated under involuntary psychiatric treatment. The essential treatment element is antipsychotic medication in depot form. The need for such treatment is lasting.

The absence of such treatment will involve a bad prognosis with a considerably high risk for new violent acts."

For good reason, the reports issued by court appointed forensic experts are 'often characterised as authoritative evidence. ${ }^{89}$ Although the sample is admittedly small, and caution certainly should be shown in drawing any definite conclusions from it, the variances here illustrated are nonetheless disquieting and should be further investigated.

Summarising this section, we may conclude that although section 62 specifies which indications the danger assessment should be based upon, and the legislator has explained how these are to be understood, challenges might still face the jurist when assessing whether these are present, as specialist knowledge is required to do so.

From a clarity perspective, an additional challenge arises from the fact that danger may also apparently be established based on other factors than the ones listed in the rule..$^{90}$ Illustrative examples may be found in the Norwegian Supreme Court verdicts, e.g., in the second verdict from 2006, ${ }^{91}$ where the Supreme Court deliberates on the defendant's housing conditions, medication, the mental health care already in place, and substance abuse in the danger assessment, thus including two factors not mentioned in the present rule.

Contrary to the impression left by the rule itself, a distinct line separating the factors on which the definition of danger rests can therefore perhaps not be drawn after all. The hope that the provided specification of elements indicative of danger can settle the worries for arbitrariness must be adjusted accordingly. 


\section{Factual Assumptions}

Neither the Penal Code itself, the legislator's earlier preparatory works, nor the new proposal for revision provide clear directions on what factual assumptions and time horizon the danger assessment shall be based. ${ }^{92}$ As discussed in section 2.1 above, this could be problematic, as having different future scenarios as a basis for the danger assessment might actually imply different rules that can lead to very different conclusions on whether danger is present.

One might reasonably interpret the legislator's definition of impending danger to mean that a possible danger must be probable/likely to materialise within a certain time horizon. However, according to court decisions that draw comparisons with similar requirements in other statutes, this is not correct:

\footnotetext{
'The appellant has asserted that it in the requirement that the danger must be impending in addition to serious, lies a time perspective [...].

I agree with the High Court's statement on the legal interpretation:

"The High Court cannot see that there are any grounds for support, in the legislator's preparatory works or other legal sources, for the view that the danger criteria contains any limitation as here implied, and will add that it cannot be demanded that the danger will materialise within a clearly defined time horizon. In the High Court's opinion, this also follows from the fact that the similar question for the treatment criteria is solved directly in the rule itself and is treated thoroughly in the legislator's preparatory works. Several other regulations contain the limitation 'impending danger', among others the Penal Code section 39 (not in force), the Criminal Proceedings Act sections 171 and 198, the Immigration Act section 15 and the Enforcement Act sections 11-14. In all of these regulations the term 'impending' shall be interpreted as a clarification that the danger must be real and sufficient on the time of the verdict. This must also be interpreted as the contents of the Mental Health Care Act section 3-3. The time factor will, however, have to be included in the Court's assessment of the concrete predictability. The further ahead in time, the lesser is the certainty that the danger will materialise."

I am furthermore on the grounds of a concrete probability/likelihood assessment in agreement with the High Court that a discharge will entail a real and sufficient danger to others life and health $[\ldots]^{193}$
}

As for the other factual assumptions, it has, following the Supreme Court verdict from $2003,{ }^{94}$ been argued that the danger assessment must have as its basis a hypothetical

92 Jacobsen (2004) pp. 110-111.

$93 \quad$ Rt. 2001 p. 1481 (270-2001)

94 Rt. 2003 p. 1085, the prosecution's appeal of the High Court's acquittal of a man diagnosed with reactive paranoid psychosis, who in the district court had been sentenced to the former special penal sanctions after having murdered his cohabitant while criminally insane due to psychosis at the time of the act. 
worst-case scenario where the offender is not receiving any mental health treatment. ${ }^{95}$ The following excerpt from the verdict's paragraph 19 may serve as an illustration:

'It is apparent from the psychiatric declarations given in the case, further elaborated in the testimony of professor M.D. Berthold Grünfeld for the Supreme Court, that the danger that A again will commit a serious offence, such as homicide, is closely connected to the danger of a new psychotic outbreak. On the basis of the same psychiatric evaluations, I must assume that the danger of recidivism is imminent if $A$ were to abort his treatment with antipsychotic medication, for instance due to failing motivation in the forthcoming phase of re-establishing as normal a life as possible outside an institution. [...]. ${ }^{96}$

Furthermore, in paragraph 29:

'The immediately forthcoming phase of rehabilitation outside an institution will be a critical phase. A has never lived alone, and he will be exposed to challenges in a completely different way than has been the case in his shielded existence until now. In my opinion there is a real danger that in this phase a situation could occur where A will be less motivated to follow up the treatment with antipsychotic medication. In this picture it must also be taken into consideration that $A$ has periodically had considerable problems with substance abuse.'

This also seems to be the starting point in later Supreme Court verdicts. In the verdict from 2005, ${ }^{97}$ the Supreme Court further clarifies this outset:

'In my opinion there is a sufficient danger of aggressive behaviour if the involuntary medication of $A$ is discontinued, and an impending danger that he then again will commit a serious offence that violates or endangers the life, health or freedom of others. The defence counsel has argued that this danger is not present at the time of the verdict, as the defendant already receives involuntary medication under the Mental Health Care Act. Even though the basis for the danger assessment is the situation at the time of the verdict, this assessment must, however, in my view also include the preconditions for this situation, ref. Rt-2003-1085 paragraph 29 onwards. Even though the defendant in that case was subject to voluntary mental health care, the verdict shows that it is necessary to consider the situation if this protection was to be discontinued. It is unquestionable that stability in the medication is a necessary precondition for there not being a sufficient danger that A again will commit serious violent acts. The requirement of danger is thereby in my opinion met. . $^{98}$

In 2006, this changes. This year, the Supreme Court makes two verdicts on the former Penal Code section 39 (now 62), the second of which constitutes a definite change. In the Supreme Court verdict Rt. 2006 p. 1137, sanctions were employed under the former Penal Code section 39 (now 62) after a criminally insane offender was acquitted

Jacobsen (2004) p. 111, with further reference to Rt. 2003 p. 1085.

Rt. 2003 p. 1085 paragraph 19.

Rt. 2005 p. 1091, where a man diagnosed with paranoid schizophrenia and paranoid psychosis had been convicted of murder by blunt violence.

Rt. 2005 p. 1091 paragraph 20. 
by the High Court ${ }^{99}$ on the grounds of criminal insanity (utilregnelighet) for several offences, including three counts of threats in violation of the former Penal Code section 227. On the danger assessment, the Supreme Court concludes:

'After an overall assessment of the offences committed by A, seen together with his histo$r y$, illness development, and mental functional capacity, my conclusion is that there is an impending danger that $A$ again will commit a serious offence that violates or endangers other persons' lives, health or freedom if society does not make provisions for his treatment.'100

Decisive for the Supreme Court's confirmation of the High Court's verdict of sanctions under the Penal Code, was a lack of confidence that civil commitment under the Mental Health Care Act, administered by the hospital, would be sufficient for the protection of society. It could be argued that the Supreme Court, in asking what measures are necessary to avoid an impending danger of future offences, based the danger assessment on a best-case scenario, i.e., what measures must be in place for everything to go well. This situation is, however, different from the former cases, as the worst-case scenario-no treatment at all-was already in effect. It is, therefore, uncertain if this verdict can be interpreted in such a way.

In the second verdict, Rt. 2006 p. 1143, the index offence was a recent minor assault, which was seen as closely correlated to an earlier serious aggravated assault. The expert witnesses had established a causal nexus between the defendant's mental illness and the violent acts committed. On several occasions, the experts had assessed the defendant's risk of future offences. In a forensic expert report from February 2005, it was concluded that a high risk of future offences would be present if the defendant was discharged to his own residence without further measures in place. In addition to consistent and structured living arrangements, as well as adequate medication, avoidance of substance abuse was considered important to reduce the risk of future offences. In recent years, the defendant had been civilly committed under the Mental Health Care Act, and was regularly medicated without his consent. $\mathrm{He}$ visited the hospital once a week for depot medication and had mostly resided in his own residence, to which mental health care personnel made regular announced and unannounced visits. In the last quarter, the defendant had tested negative for illegal substance use. In July 2006 he was, however, discovered by the police intoxicated by the roadside, which led to a conversation at the institution the following day. Thereafter, he was allowed to return to his own residence. The Supreme Court concluded that the defendant in later years had lived a relatively controlled existence, including frequent contact with and monitoring from mental health care personnel. The Supreme Court found that there was no evidence that this would change even though the defendant himself expressed discontent with the medication and lacked insight to his own mental condition. It is stated that: 
In assessing the question of danger of recurrence of such serious criminal offences as mentioned in section 39 no. 1, the psychiatric treatment regime encompassing the offender, and under which it must be supposed that he will continue to reside, must in my opinion be given substantial weight. The requirement of 'impending danger' in section 39 no. 1 ref. section 39c no. 1, is, in accordance with statements in Ot.prp.nr.87 (1993-1994) page 108, practiced such that the risk must be sufficient and real, ref. Rt-2003-1085. ${ }^{101}$

On the basis of the mental health care regime already in place, the Supreme Court found that sufficient danger for the use of sanctions under section 62 was not present. ${ }^{102}$

However, in the following Supreme Court verdict from $2010^{103}$, a hypothetical worst-case scenario again seems to form the basis for the danger assessment:

'The experts' assessment is that his prognosis is completely dependent on whether he will manage to stay away from substance use or not. They assume that he will experience a psychotic break after a few days' use of, for example, amphetamine. Also, the use of alcohol will in their opinion indicate an obvious worsening of his prognosis with an expressed impulsivity and danger for violence. This is related to his serious dissocial personality disorder in addition to paranoid schizophrenia.

A has since august 2009 been at the Fossen substance abuse treatment centre and has stayed clear of intoxicants during his stay there. It is, however, not certain that he will continue to do so if he does not have to. In light of his history of violence and threats, his mental condition and addiction, in conjunction with the fact that intoxication leads to a significant worsening of his condition, there is in my opinion an impending danger of a new offence that violates or endangers other peoples' lives, health or freedom.' ${ }^{104}$

Another variation appears in a verdict from $2011^{105}$ on the continuation of sanctions, which appears to include both a worst-case and a best-case scenario. In the danger assessment, it is initially remarked that it is clear and undisputed that the danger requirement would be met if the alternative to special sanctions under the Penal Code were that the defendant was to receive no care at all. In the following, it is nonetheless stated that other realistic treatment options must be taken into consideration:

Rt. 2006 p. 1143 paragraph 21.

It should here be noted that what treatment measures are in place has been considered part of the necessity requirement by the legislator, see section 2 above.

Rt. 2010 p. 346, where a man diagnosed with paranoid schizophrenia, dissocial personality disorder, opiate dependency disorder under treatment with methadone and hyperkinetic behaviour disorder, and with a history of violence and threats, had appealed against the High Court verdict of special sanctions under Penal Code section 62, after having found that he again-among other minor offences-had committed two serious threats while criminally insane due to psychosis at the time of the acts.

Rt. 2010 p. 346 , paragraphs 24 and 25.

Rt. 2011 p. 385, where a man diagnosed with chronic undifferentiated schizophrenia had been acquitted for the murder of four close family members in 1984 on the grounds of criminally insanity (utilregnelighet) due to psychosis at the time of the act, but sentenced to special sanctions under the Penal Code that were later upheld. 
'In the assessment of an 'impending danger' that $A$ will commit new violent acts, it must, however, be considered whether realistic treatment alternatives other than a verdict of continued involuntary mental health care are available. The defence counsel has, in relation to this, argued that $A$ wishes to receive mental health care voluntarily, and that heif this is not considered sufficient-could be civilly committed under the Mental Health Care Act chapter 3.'106

Thereafter, the Supreme Court deliberates on the danger assumed based on the two alternatives and concludes that neither offers sufficient protection of society.

As a result of the lack of guidelines given by the legislator, and the apparent variance in the scenarios that the Supreme Court considers, it remains unclear what factual assumptions of the offender's situation in the future should de lege lata form the basis for the danger assessment. In light of the possible implications for the danger assessment, not to mention when the legal issue is that of continuation of sanctions, the room for unequal treatment thus created gives cause to worry.

\section{Reflections and Conclusions}

In the discussion on the meaning of the danger requirement, I have argued that, depending on how danger is defined and on what temporal and factual dimensions its assessment is based, alternative rules might result. Danger is, for instance, somewhat different when thought to entail a possibility for future offences, than when entailing a probability/likelihood for future offences. It is, furthermore, different when determined isolated from external circumstances, compared to when viewed as contingent on given situations. Whether or not danger is considered present may also to a large degree depend on what criteria are set for its identification-what has been previously described as the situation or state element.

Despite the legislator's apparent efforts to frame the decision-making process through providing directions for the danger assessment, a preliminary analysis of legal sources has shown that the assessment is seemingly still approached in different ways in actual cases. Apparently, the courts exercise a substantial degree of discretion as to the legal meaning of the requirement. In doing so, no clear definition of the phenomenon is given, factors other than the ones listed in the rule itself are included, and the future scenario forming the basis for the assessment varies. The rule in Penal Code section 62 might therefore be further from the rule-of-law ideals of legal clarity, predictability and equality before the law, than one might initially expect. Considering the current legal landscape, I am not at all certain that different judges would reach the same conclusions, or even examine the same evidentiary topics, if presented with the same case. With regard to the intended greater emphasis on the danger requirement in the Ministry's proposal, this is troubling. 
The concluding remark must be that further legal and conceptual clarification is needed if arbitrariness in court decisions on involuntary psychiatric treatment is to be avoided. Deciding upon a commonly accepted definition and a clear set of factual assumptions for the assessments would go a long way in that direction. At present, this might prove a difficult task, as there is currently no comprehensive conceptual framework for the application and assessment of danger and risk in a Norwegian penal legal context that can serve as sufficient basis for an informed discussion on possible alternatives and consequences. Developing such a framework requires more time and resources than is available to the legislator and higher courts. More research in the field is therefore necessary. 